\title{
Balochi Oral Literature and Gender Construction
}

\author{
Nadil Shah \\ \& \\ Rana Saba Sultan \\ Department of Sociology \\ University of Karachi \\ Bashir Kaker \\ Department of Sociology \\ BUITEMS University, Quetta
}

\begin{abstract}
Language plays a vital role for the shaping of the social structure of a society. Similarly, proverbs are the significant part of any language being used in a day to day communication. These proverbs are transformed and transferred from generation to generation in according to the social events and conditions. The current study carried out on representation of women in Balochi language proverbs. The purpose of this study was to critically analyze the gender representation of women in Balochi language Proverbs. In present study purposive sampling technique is used to collect data. The data were collected from four books on Balochi proverbs among them 15 proverbs are critically analyzed. All those proverbs which represented women are taken and analyzed. Moreover, the Hegemonic masculinity, hegemony and social constructionism theories are used to analyze the data. The findings of this study suggests that women are represented in a gendered way depicting her role as dependency, submissiveness, marginalized and lack agency whereas men have been portrayed as powerful, brave, ruler and holds greater autonomy over economic, social, religious and political domain.
\end{abstract}

Keywords: Balochi Proverbs, Social Construction, Gender, Hegemonic Masculinity, Patriarchy, Submissive, Dependent and Supremacy of Men.

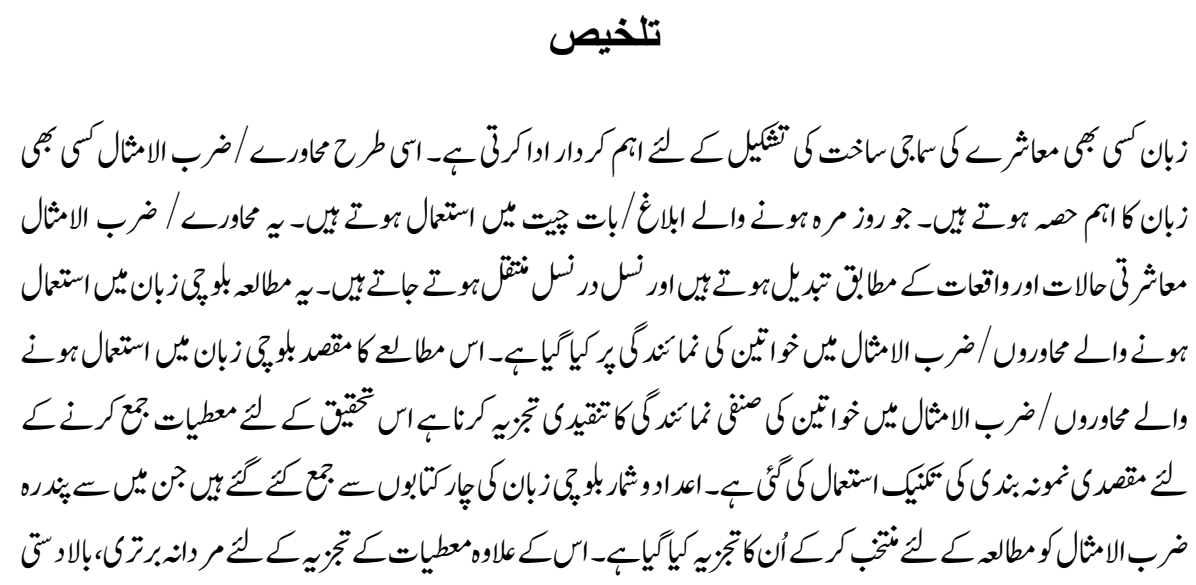




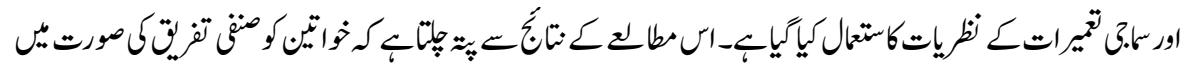

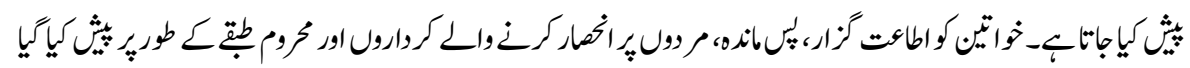

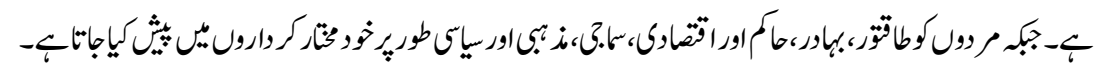

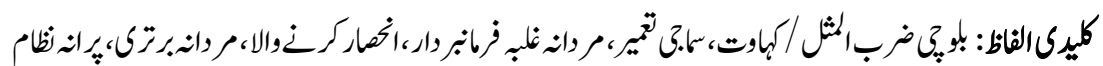

\section{Introduction}

Women are marginalized in everywhere in the world (Hussein, 2005) but the intensity of oppression differs according to the society i.e. it may be low in developed nations and higher in under developed or developing nations. Gender has become the most prominent debated topic in contemporary scholarship (Balogun, 2010). Social scientists particularly sociologists are intensively working for eradication of gender gap and disparity. Gender has developed a field of study in the world which deals with different gender related issues. Many researches have been conducted on this topic by field experts on different aspects of gender, such as construction of gender through Textbooks (See Ullah and Skelton, 2013, 2016), Gender and Media (see Ullah and Khan, 2014) and so on. The Penguin Dictionary of Sociology defines gender as $\left(5^{\text {th }}\right.$ Edition) "Gender is a socially constructed phenomenon which is related to or determined by biology (Abercrombie, et al. 2006, p.149)". So, Gender has socially constructed roles assigned to men and women in a society according to their sexes. The present study concentrates on social construction of gender through proverbs.

The proverbs play a pivotal role for the construction of knowledge in a society because these are developed from the social and normative structure of a society. Proverbs are the fruits of human wisdom because these represent the hidden aspects of culture and thoughts of a society (Storm, 1992). It is a kind of language through which we can communicate messages. As Hussein (2005) argued, language is a symbolic act of both representing and value things. Through these proverbs society perceives and expects similar activities and roles from male and female according to their gender. On other hand, both genders (Male and Females) follow the concepts of 'self-fulfilling prophecy' (Colhoun, 2010). The present study is conducted on Balochi proverbs. The word Batal is used for proverb in Balochi language and proverbs have great importance in oral Balochi literature (Khan, 2000). The purpose of the study is to know how women are presented in Balochi proverbs and what kinds of reactions are showed by both genders while following proverbial expressions.

\section{Literature Review}

Proverbs represent the thoughts and social structures of the society and gender based proverbs clearly show the different social positions of males and females in the society. 
Hiroko Storm (1992) mentioned some traditional Japanese proverbs in his article Women in Japanese Proverbs that women are shown as inferior, stupid, submissive, changeable, talkative, weak etc. and on the other hand, men are presented as Inexpressive, reasonable, strong intention, tough, reliable etc. Further, he said that after Second World War the status ofJapanese's women became better because of equal opportunities but they had to leave works because of marriage and childbirth due to which they could not play their role in the society. He said that in proverbs women are showed as servants of husband so she must obey him. Further Jeylen W. Hussein (2005) writes that women are represented as weak, evil, unfaithful and dependent etc in African proverbs and on the other hand men are legitimized to be subordinate and practice their power over women.

Wolfgang Mieder $(1987,1989)$ argued that proverbial language is not only used in spoken languagein American society rather it became the prominent language in Media such as advertisement, stickers etc (Cited by Prahlad, 2004). Proverbs usually represent the traditional wisdom were the folks of the past.

AbasiKiyimba has conducted a research on Oral literature on Baganda(Uganda) society and Cited a proverb "One who will become favorite, begins by giving birth to a baby boy" (2005, p.255).This Proverb depicts that boy baby is appreciative and girls are not even a woman who gives birth of boy baby is praised, loved and favorite. On contrary, she is blamed for giving birth to a girl though it is not in the hand of mother. Another two proverbs cited by Kiyimba "The son in his father's seat" and "Girls as social and material wealth" (Kiyimba, 2005, pp. 257-58). These proverbs clearly show that son (boy) is going to be the head of home and girl is just temporarily gives some materials to her father when she gets married, after which she will be taken by a groom and would be stilled with her husband. Similar argument is given byHelen Yitah (2009) who cited a proverb in his research article titled "fighting with proverbs": Kasena women' redefinition of female personhood through Proverbial Jesting that "She is a dog of two houses". There are two homes for a girl, one is her father's and second is husband's one where she will go after marriage. He said this proverb reflects the unreliability of women. Kiyimba (2005) mentioned another proverb and said that girl is responsible for the maintenance of respect of the family.

Hussein (2005) claimed that meanings of the proverbs have harmful effects on women attitudes and behaviors. He said that what society communicates with people according to the sex, it represents the social thought about both genders. In concluded he argued that that African proverbs were promoting gender biasness such as males are associated with powerfulness, capability and strong and women are associated with humbleness, changeability and weakness.

OledeleAbiodunBalosun (2010) said that negative proverbs are effecting the marriage in Nigerian society because most of the proverbs express that women should not be trusted, 
and in proverbial pictures shown that men should be suspicious, dishonest and secrecy which may contribute for the separation of couples. These may cause frustration and dependency of women and effects the empowerment of women (Balosun, 2010). Further, he said Yoruba men are using these proverbs for justifying the patriarchal position and practice their hegemonic power over women.

Meryem Belfatmi (2013) cited Yksel (1993) in her article The representation of women in Morocco Proverbs which she said that women perceived as evils and mostly associated with animals such as dogs, horse etc in proverbs through which people using false generalization which creates more false conception about women. Further she said that women are shown as beautiful, unintelligent, runner of the house, treated as animals, evils etc. Further, she cited some Morocco Proverbs and said that woman are beaten to be submissive and those proverbs which are about violence against woman or beating women are indirectly indicate to force women to be submissive and dependent on male member.

Noor Sanauddin (2015) in his Ph.D. thesis Gender and proverbs in Pashtun society used some theories while analyzing the proverbs such as "hegemonic masculinity" by Connell, theory of 'deficit', 'dominance', 'difference' and 'community' of practice -which believe that there is sexism in language. Man speaks/uses different language and female another. Man's language presents his dominancy in the society and female's language shows submissiveness. It also believes that language is a tool used for suppression and subversion at the same time (Sanauddin, 2015).Dr. Shahid Siddiqui (2008) added that, "Since language is a powerful tool to construct social reality with, women, by the use of sexist language, are being dubbed as inferior and deviant. Sanauddin used "Intersectionality" theory by Crenshaw, "patriarchy" by Walby's, Theory of "patriarchal bargain" by Kandiyoti's (1988), theory of "patriarchal gender contract" by Moghadam (1992) to analysis the gender relations and language in a society (See Sanauddin, 2015).He has also cited Dupree (1979) that proverbs promote existing social system rather than questioning it.

Gender based proverbs are constructed through commonly-held beliefs about masculinity and femininity. As Sarwet Rasul collected definitions of proverb from different sources and concluded that "proverbs are based on precision, originated from human experiences, social phenomena, folklore and general truth $(2015$, p.53). Further, She said that there is no absolute truth available in those definitions because it is the social interpretation of truth. Proverbs are not scientifically proved rather these are based on commonly-held views and constructed according to the situations, events, experiences which were occurred in a society with the particular time period. By these experiences, events and conditions, the proverbs are constructed and became common in the broader society. On the other hand, proverbs reflect the normative structure of society such as beliefs, norms, life style of that particular society.

The oral traditions (i.e. songs, folktales, stories and proverbs) can also influence the member of the community where this common knowledge is prevailing and they strictly 
follow them. As Dominguez said, "Oral traditions influence the way members of any given community think, thus, how they perceive and feel about the world around them (2010 cited by Rasul, 2015, p.54)."So, the women also strongly follow these oral traditions though these are miss represented and against their social rights. Women usually follow, whatsoever is told to her by male family members such as her father, brother, husband or son (Rasul, 2015) because of submissiveness. Women are also compared with evil and sometimes she is said to be worse than devil (Rasul, 2015)

Finally Balogun (2010) suggested that all responsibilities of the problems presented in African proverbs should not be given to women such as separation, falseness, sexual immorality and so on rather these proverbs should be revisited and reconstructed. We should give awareness about the hidden realities of language discourse to our young generation. As Balfatmi (2013) said that as much as awareness we give to the people about such biased and stereotypical concepts in proverbs, as much they will avoiding by using them and there is high chance of social equilibrium in the society. Sanauddin (2015) has concluded his study that the construction of proverbs are unequal because most of the proverbs are produced by men. The proverbs clear depict power relation and social ranking of male and female. Susan Geiger suggested that we should accept the interpretations of women about their identity because it is based on their experiences of social world which exactly reflects their social reality (cited by Yitah, 2009).

\section{Theoretical Framework}

Gendered discourse is very popular in our daily use language. It is common in day to day language that we use to communicate with each other. There are different theories about gender which deal with gender inequality and gender interaction in each society. As Raewyn Connell (1995) theory Hegemonic masculinity clearly claims that how women are being subordinated by men in society. As Connell (1995) defined that "Hegemonic masculinity to explain the practices that promote the dominant social position of men and the subordinated social position of women (cited by Sanauddin, 2015, p. 60)." This theory believes that men usually try to legitimized their power through the help of creating patriarchal discourse in daily life communication. So, In the context of Baloch society, the men use gender biased proverbs to justify and legitimized their supremacy over women. The present study is analyzed with help of this theory, that men have legitimize their masculinity on women with help of daily used Proverbs. One theory cannot be enough for analyzing this study rather Antonio Gramsci's concept 'Hegemony' is also used for analyzing the data. According to Gramsci (1971) hegemony means dominance of one group over other through their consent because dominated group thinks that it is for the betterment of them actually it is not. But in this study, the concept of hegemony is not used as Gramsci did because he applied it on politics. In this study, it is used on Gender. How men are practicing and legitimizing their power on women and they have maintained their social position in the society through the consent of women by using different proverbs in their daily communication? For eliminating 
this negative discourse, the women should go for 'counter Hegemonic struggle (Gramsci, 2000)' to eradicate this fake discourse through 'war of position' in the form of struggle over traditional constructed ideas and belief which are shown in proverbs. Peter L. Berger and Thomas Luckmann (1991) theory social construction reality is also applied on this research. Berger and Luckmann (1991) said that reality is socially constructed which is based on 'commonsense knowledge' and social structure of society because commonsense knowledge is usually in support of powerful segment of society (Ullah and Ali, 2012). Social constructionists believe that knowledge is constructed through social interactions with others (Mackinley, 2015). Further, he said that the qualitative researchers should use it a theoretical framework while analyzing the social interaction of the people. In this study, the social constructionism is used for analyzing the proverbs and how people interact with each through gender based proverbs and create their social reality. Researchers also critically analyzes the effects of gender biased proverbs for shaping the life style of women because it is the game of language. "Language does not mirror the reality, rather it constitutes (Create) it (Fairhurst and Grant, 2010, p. 174)." As it is said in hegemony that 'knowledge' is a social construct that serves to legitimate social structures (Haywood, 1994, p.101)".

\section{Methodology}

The present study is carried out through the help of qualitative method. Qualitative research is focused on quality of a phenomena because data are proverbs which are in the shape of statements.This approach also helps the researcher to analysis the data through interpretation or subjective meanings of the proverbs. Another reason is, the researcher and supervisor command on this approach. The data were collected from four different Balochi

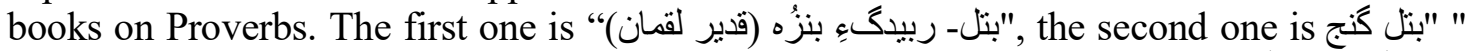

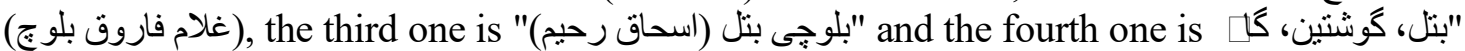
. These books were selected because these books are famous in Baloch educated society and these writers also have more command on Balochi literature. Books were selected through purposive sampling techniques. The purposive sampling also called deliberate sampling (Kothari, 2014) which means select respondent which fulfill the researcher's purposive. These books are thoroughly read and collected all proverbs which were related to both (male and female) gender. Secondly, all those proverbs have been taken from selectee which represented women. After all, researchers have selected fifteen (15) proverbs to analyze them. The data were analyzed through the lens of different sociological theories such social constructionism by Peter Berger and Thomas Luckmann, Raewyn Connell's theory of Hegemonic masculinity and Hegemony by Antonio Gramsci, as discussed them detail in theoretical framework.

\section{Key Findings and Discussion}

Gender based proverbs show that women should be or force them to be submissive and dependent on men (See Belfatmi, 2013 in Review of literature section). Here 
submissiveness and dependency means those proverbs which represent those females are submissive and dependent on their male members in family as well as on broader society. Balochi proverbs also represent devil and degrade women on the basis of gender. These also promote the supremacy of men over women.

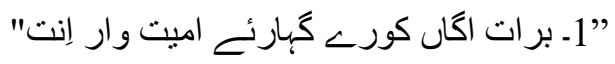

(Sister expects from brother though he is blind)

Proverb No 1. This proverb is communicated when sister needs help from brother but he does not fulfill her need.In this proverb, sister (female) is dependent on her brother. It stands to reason that blind people are mostly dependent and in most of cases are desperately in need of help from a physically fit and fine person. But surprisingly, the proverb's meaning gives superiority of a blind brother (male) over a physically sound sister (woman) which is totally against the rationality. However, yet the brother (male) has more power which shows the supremacist thinking of men in Baloch society. The proverb is a classic example of men' attitude towards women which depicts that however a man is he or she is better and superior.

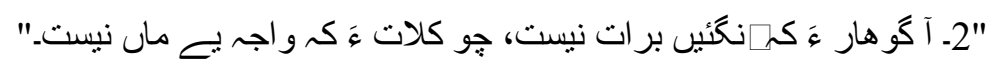

(If a sister is without a brother, she is like that fort which is without king.)

Proverb No 2. It is popular in Baloch society that fort is usually headed by a king who is a male head/tribesman. Here it means that a male can only safeguard and protect. The concepts of kingdom represent power and dominancy. This proverb clearly shows the power relation in the society because there is external threat for fort when it does not have a king. So, in this proverb, sister (female) is compared with fort and brother (male) with kingdom which is power. The hidden message here is that a sister (female) is nothing without a brother (male) because there is external threat for her. So, the brother is very important for the survival of the sister without whom her existence or survival is in threat.

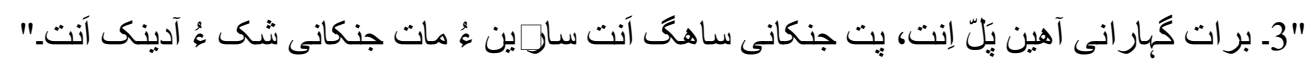

(Brothers are like protecting walls for the sisters; father is the cold shadow for daughters and mother is the comb and mirror for the daughters.)

Proverb No 3. This proverb is clearly presenting the patriarchal structure of society in which female is inferior and male is superior because brother (male) is compared with strong walls which is showing the security and protection. Father (male) is compared with cold shadow which is important as well as need of everyone and it is also showing that softness which is attached to women. On other hand, mother (female) is compared with comb and mirror which represents the beautification because beautification and sexism is attached with female. The mirror also represents the imagination which shows that woman are usually in imaginary world and cut off from the real world.The most important thing here is the question of the existence or identity of a daughter. So the existence of girl has completely disappeared. This proverb is clearly showing the dependency of women on men because men are the only ones who can give protection, 
security, and comfort places for other family members and females are just for beautification and cut off from the real world.

$$
\begin{gathered}
\text { "4 جن ءَ را مرد دار إيت-" control a wife.) } \\
\text { (A husband (powerful) can control }
\end{gathered}
$$

Proverb No 4. In this proverb, woman is represented as 'docile body'. Because it is showing that husband (male) is the only power and he can control his wife (female). The hidden message is communicated here is that controlling power is man whatsoever he says.The woman should follow because she is dependent on her husband. Another, message is that woman cannot take good decisions because she is unplanned and unsystematic. So it is the duty of husband to plan and help her to take right decisions because the intelligentsia of woman is weak like a child. Thus, she has to be dependent and submissive to her husband. Indirectly, this proverb is also saying that husband has power to practices on his wife to control her.

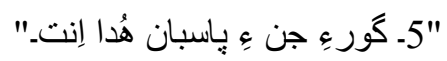

(God is the security of Jewel's wife)

Proverb No 5. Here the word " كور" means Hindu (Hashumi, 2009, p.707) but generally it is attached with Jewel (a person who makes necklace and other decorative materials particularly for females). In history, Hindu or Christens usually did house works for others due to which their wives were alone at their own houses. It was famous that wife should not be alone at home. So, this proverb is clearly showing that woman is dependent because she needs security and protection from man. But in real sense, she has threat from man and he is the one who gives protection to the woman.

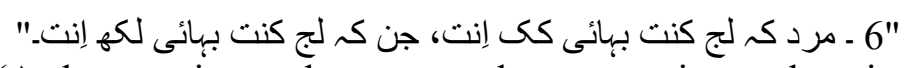

(A shy man is worth a goat, a shy woman is worth a city)

Proverb No 6. This proverb is said when a male shies in front of the people and female does not shy in front of the people. The shyness is attached with female because she is responsible for maintenance of honor of the family and society. If a boy shies, he will be blamed because he will have to be involved in public affairs. Therefore, this proverb promotes submissiveness of women because females are being forced to be silent which is attached to submissiveness. If a person is motivated to be talkative and forced not to shy means promoting him/her to be super massive. In this proverb, females are forced to feel shy in front of people and males are motivated to talk. Indirectly, women are directed to be submissive to male members.

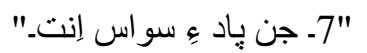

(Wife is like a shoe for foot)

Proverb No 7. In the given proverb, the woman is compared with shoe for foot because shoe itself does not have any say. Whatsoeverthe direction is given it fallows. So shoes 
are the followers of feet and the human who is wearing it. Similarly, woman is submissive to man. Whatever direction is provided by man (foot), the woman (shoe) should follow. The wife should follow the instructions and dictations of her husband.

$$
\text { "8 - هركس وَى جنِ جود عُ جُكانى بِت إنتـ." }
$$

(Everyone is the husband of his wife and father of his children.)

Proverb No 8. The word "جود" means husband (Hashumi, p. 381) but it is not popular in common Balochi language. In Baloch society the word "مرد" is used for husband. The word husband itself represents supremacy of man because husband is the head of family who is responsible for the maintenance and earnings of the house. This proverb is clearly showing that man is the husband of his wife and father of his children. So the responsibility of husband is to provide education, health and food to children and solve other issues related to home. It is clear that man is the superpower at home.

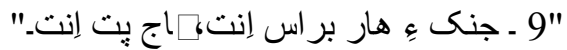

(A girl's necklace is brother and crown is father.)

Proverb No 9. This proverb is clearly showing the supremacy of male because necklace is brother which tight on her throat and father is crown which is on her head. If the throat and head are occupied then a person can't do anything because he or she is totally controlled. So the girl is totally controlled by her brother and father. Therefore, it clearly shows supremacy of man over a woman.

$$
\text { "10ـ نا مرديء جن روت بله مردِ دشتارنح روت." }
$$

(Docile man's wife can leave and become someone else's wife but a strong man can even dictate his fiancé.)

Proverb No 11. This proverb is quoted when a fiancé of a boy leaves or gets engaged with someone else without the consent of fiancé. In Baloch society, if a boy gets engaged with a girl then no one is able to take that girl from him without his consent. If the girl is engaged with other boy without his consent, he is labeled " $N a$ ' Mard" (a man who does not have man power). The person who is docile ( $\mathrm{Na}^{\prime} \mathrm{Mard}$ ), his wife can go/ taken by others but if you are strong boy (Mard) no one can take your fiancée. So this proverb vividly says that man is powerful, and girl is just a 'docile boy'. So whatsoever a boy wants that will be acceptable otherwise girl has no say in front of male. Even in Baloch society a fiancé could give to other people without consent of girl (Read Shay Mureed and Hani story) because Hani was the fiancée and cousin of Shay Mureed and she was given to Chakar.

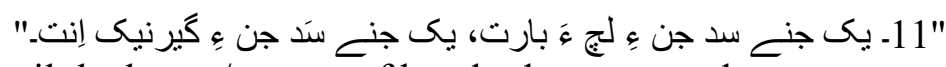

(One woman can spoil the honor/respect of hundred women and one woman can maintain the honor/respect of hundred women) 
Proverb No 12. It is said when a woman does not have good reputation in the society because she wants to live independently and freely. It is clear that a woman is responsible making good and bad reputation of other women in the society. If one woman is open minded or 'Be gerath' according to the popular society, she will make all other woman bad in the society. One case is generalized on all women in society because of patriarchal structure. The purpose of generalization is to maintain the dominancy of men over woman. So if she wants to make good reputation in the society, she will have to follow the instruction of patriarchal structure of society otherwise her bad character is responsible for creating bad names for other women in the society. But in actual sense, a woman is not responsible for the respect of other because everyone is responsible for his/her actions.

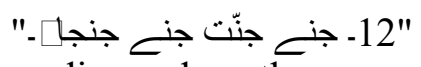

(One woman is paradise and another woman is hell)

Proverb No 13. This proverb is mostly said when a wife does not obey her husband or given instructions of society. In this proverb woman is compared with paradise and hell. A wife will be called paradise if she facilitates her husband and follows the instruction of husband and serves the interest of husband. A wife will be humble if she does not go on 'social road' of society. On the other hand, she is hell for her husband, when she does not follows or rarely follows the recommended rules of husband. Despite being a colleague, she is expected to assist the husband in the society which is against human nature because all human born equal despite any gender difference.

$$
\text { "13- جنيس عِ يار شيتان إنت." }
$$

(Woman is the friend of evil)

Proverb No 14. It is also said that woman does not obey her male because it believed that woman can easily be fooled due to her unintelligence. She is the friend of evil because evil usually brings those people in his way and she does not have enough understanding about good and bad. Evil becomes the friend of those who take decisions being inspired from emotions. So women are said to be emotional creature that take decisions or act according to their emotions.

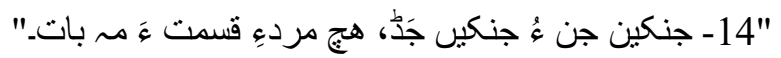

(Childish wife and camel calf should not come in the fate of someone)

Proverb No 15. This proverb is said when a wife does childish works and childish camel "Jud" (a small camel which is newly ride able) (Hashumi, p. 369). If camel is a small and newly in ride age, it will create a hurdle for owner. Similarly, a small wife is also a hurdle for the husband. There are two concepts which are attached with female/Woman. Firstly, she is analogized with animals and secondly with the concept of childish because both have bad names in the society.

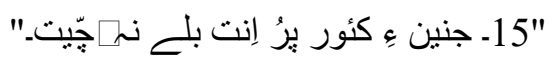

(A woman's river never flows though it is full) 
Proverb No 16. In this proverb woman is attached with river. In this proverb, two concepts are there. Firstly, it is showing that woman cannot be perfect and secondly woman desires more and more or the desires of woman are uncountable. In the first concept, the river is full but does not flow which shows that she is a person with a body which everyone has but cannot take decisions. In second point, the river is full and does flow means all demands are fulfilled but she is still in need of more. It is totally degradation of woman through proverbs.

\section{Conclusions and Recommendations}

It is to think upon construction of gender through proverbs which are based on traditional myths and experiences which are passed from generation to generation. This study was carried out to know the presentation of women in Balochi proverbs. It was concluded that women are represented as submissive, dependent, and unintelligible and derogatory terms have been used for women etc. These proverbs are also promoting the supremacy of men over women and men are legitimized to practice their power over women by the patriarchal social structure of society. These myths and traditional thinking about woman in Balochi proverbs show the patriarchal structure society from history. These all are socially constructed and men who practice their hegemonic power and promoted masculinity in the society. Due to which, the men have power to manipulate and shape the social structure of society according to the interest of their own. It is high time to revisit to such myths, traditional proverbs about gender and reconstruct them with new ideas to promote gender equality in the society because women are the important segments of society. The women are not only responsible for bad occurrence in the society rather both men and women are equally important for destruction and construction of society.

This study may not be generalized to the proverbs such as Pashtun, Sindhi, Punjabi and other languages in Pakistan due to its limited scope. There is also few literature available on gender and proverbs in Pakistani languages and more studies and researches need to be conducted in this area particularly Balochi language. Studies need to be carried out on gender construction and folk tales and songs in other Pakistani languages generally and Balochi language particularly. Most importantly, This study is very important while including proverbs in syllabus and curriculum development of the school textbooks.

\section{Reference}

Abercrombie, N., Hill, S. \& Turner, B. S. (2006). The Penguin Dictionary of Sociology. Penguin Books.

Badal Khan, S. (2000). Ropes Break at the Weakest Point. Some Examples of Balochi Proverbs with Background Stories. Proverbium-Columbus Then Burlington, vol.17, pp.43-70.

Baloch, G. F. (2011). BatalGanj. SayadHashmi Reference Library 
Balogun, O. A. (2010). Proverbial Oppression of Women in Yoruba African Culture: A Philosophical Overview. Thought and Practice, New Series, vol.2:1, pp.21-36.

Bellis, A. O. (1996). The Gender and Motives of the Wisdom Teacher in Proverbs7. Bulletin for Biblical Research, vol.6, pp.15-22.

Berger, P. \& Luckmann, T. (1991). The Social Construction of Reality: A Treatise in the Sociology of Knowledge. Penguin UK.

Belfatmi, M. (2013). The Representation of Women in Moroccan Proverbs. IOSR Journal of Humanities and Social Sciences, vol.17:1, pp.15-21.

Calhoun, C. (Ed.). (2010). Robert K. Merton: Sociology of Science and Sociology as Science. Columbia University Press.

Creswell, J. W. (2007). Qualitative Inquiry \& Research Design: Choosing Among Five Approaches (2nd ed), London, Sage.

Connell, R.W. (1995). Masculinities, Cambridge, Polity Press.

Daramola, A. (2007). SokoroSakara: A Contextual and Gender Analysis of Some Offensive Yoruba Proverbial Songs. Nebula, vol.4:4, pp.121-30.

Dupree, Louis. (1979). Functions of Folklore in Afghan Society, Asian Affairs, vol.66:1, pp.51-61.

Dominguez, B. E. (2010). Function of Proverbs in Discourse: The Case of Mexican Transnational Social Network. Series- Contributions to the sociology of language USA: Walter de Gruyter.

Fairhurst, G. T. \& Grant, D. (2010). The Social Construction of Leadership: A Sailing Guide Management Communication Quarterly, vol. 24:2, pp.171-210.

Gramsci, A. (2000). The Gramsci Reader: Selected Writings, 1916-1935. NYU Press.

Geiger, S. N. (1986). Women's life histories: Method and content. Signs: Journal of Women in Culture and Society, vol.11:2, pp.334-351.

Heywood, A. (1994). Political Ideas and Concepts: An Introduction. Macmillan Publisher.

Hussein, J. W. (2005). The Social and Ethno-Cultural Construction of Masculinity and Femininity in African Proverbs. African Study Monographs, vol.28:2, pp.59-87. 
Kandiyoti, D. (1988). Bargaining with Patriarchy. Gender \& Society, vol.2:3, pp.274-290.

Kiyimba, A. (2005). Gendering Social Destiny in the Proverbs of the Baganda: Reflections on Boys and Girls becoming Men and Women. Journal of African Cultural Studies, vol.17:2, pp.253-270.

Kothari, C. R. (2004). Research Methodology: Methods and Techniques. New Age International.

Luqman, Q. (2012). Bathal-Rabedag'ebonzah. Al Balochistan Academy Turbat.

McKinley, J. (2015). Critical Argument and Writer Identity: Social Constructivism as a Theoretical Framework for EFL Academic Writing. Critical Inquiry in Language Studies, vol.12:3, pp.184-207.

Mieder, W. (2015). Tradition and Innovation in Folk Literature. Routledge.

Mieder, W. (Ed.). (1989). American Proverbs: A Study of Texts and Contexts, (Vol. 13). Herbert Lang Et Company Ag.

Moghadam, V. M. (1992). Patriarchy and the politics of gender in modernising societies: Iran, Pakistan and Afghanistan. International Sociology, vol.7:1, pp.35-53.

Olasupo, F. A., Kikelomo, M. O. V. \& Adeniran, J.A. (2012). Proverbs and Gender Equalities and Equities in African Cultures: Yoruba Culture as A Case Study. Global Journal of Human-Social Science Research, vol.12:13.

Prahlad, A. (2004). You Took the Words Right Out of My Mouth: Proverbial Expressions, Feminist Perspectives, and the Fetish in the Work of Janet Davidson-Hues. Journal of American Folklore, vol.117:463, pp.22-54.

Ragam, S. (2012. Batal, Goshthin o Gaal Band. Balochi Academy Quetta.

Rahim, I. (2017). Balochi Batal.AbabagarKalmati Academy Pallery Gawadar.

Rasul, S. (2015). Gender and Power Relationships in the Language of Proverbs: Image of a Woman. FWU Journal of Social Sciences, vol.9:2, pp.53-62.

Sanauddin, N. (2015). Proverbs and Patriarchy: Analysis of Linguistic Sexism and Gender Relations among the Pashtuns of Pakistan (Doctoral dissertation, University of Glasgow).

Sandoval, T. J. (2007). Revisiting the Prologue of Proverbs. Journal of Biblical Literature, vol.126:3, pp.455-473. 
Storm, H. (1992). Women in Japanese Proverbs. Asian Folklore Studies, vol.51:2, pp.167-182.

Siddiqui, S. (2008). Gender Bias in Language in Daily Dawn, Retrieved on August 13, 2017from Dawn: https://www.dawn.com/news/844014

Walby, S. (1990). Theorizing Patriarchy, Oxford, Blackwell Publishing.

Williams, F. C. (2001). Scottish Proverbs: A New Walk in an Old Field [1]. Folklore, vol.112:1, pp.73-82.

Wolfrang, Yksel. (1993). Women in Proverbs. Oxford University, pp.65-66

Yitah, H. (2009). Fighting with Proverbs: Kasena Women's (Re) Definition of Female Personhood through Proverbial Jesting. Research in African Literatures, vol.40:3, pp.74-95.

Ullah, H. (2012). Male Hegemony through Education: Construction of Gendered Identities. Multidisciplinary Journal of Gender Studies, vol.1:3, pp.215-242.

Ullah, H. \& Skelton, C. (2013). Gender Representation in the Public Sector Schools Textbooks of Pakistan. Educational Studies, vol.39:2, pp.183-194.

Ullah, H. \& Khan, H. N. (2014). The Objectification of Women in Television Advertisements in Pakistan. FWU Journal of Social Sciences, vol.8:2, pp.26-35.

Ullah, H. \& Skelton, C. (2016). Social Reproduction of Gender Hierarchies in Sports through Schooling in Khyber Pakhtunkhwa. Asia Pacific Journal of Education, vol.36:1, pp.131-144.

Nadil Shah is M.Phil. Scholar in the Department of Sociology, University of Karachi.

Dr. Rana Saba Sultan is Professor in the Department of Sociology, University of Karachi.

Dr. Bashir Kaker is an Assistant Professor in the Department of Sociology, Balochistan University of Information Technology, Engineering and Management Sciences, Quetta. 